\title{
Soil Compaction Due to Wood Harvesting Traffic at Different Extraction Distances
}

\author{
Carla Krulikowski Rodrigues ${ }^{1}$, Eduardo da Silva Lopes ${ }^{2}$, \\ Karina Maria Vieira Cavalieri Polizeli³, Marcelo Marques Lopes Müller ${ }^{4}$ \\ ${ }^{1}$ Programa de Pós-graduação em Ciências Florestais, Universidade Estadual do Centro-Oeste - UNICENTRO, \\ Irati/PR, Brazil \\ ${ }^{2}$ Departamento de Engenharia Florestal, Universidade Estadual do Centro-Oeste - UNICENTRO, Irati/PR, Brazil \\ ${ }^{3}$ Departamento de Solos e Engenharia Agrícola, Universidade Federal do Paraná - UFPR, Curitiba/PR, Brazil \\ ${ }^{4}$ Departamento de Agronomia, Universidade Estadual do Centro-Oeste - UNICENTRO, Guarapuava/PR, Brazil
}

\begin{abstract}
This study evaluated the effect on Oxisol soil compaction of traffic by wood harvesting machines from different extraction distances carried out by a logging company located in Paraná State. The harvesting system was composed of a feller buncher, skidder and harvester, in which soil compaction was evaluated at four extraction distances and four depths by means of density, porosity and soil penetration resistance. Increased machine traffic resulted in the highest compaction in the soil surface layers on the extraction trail, with the highest intensity in the region near the edge of the stand and with values above the critical density limits. Soil penetration resistance was critical in the row of traffic over the stand with significant effects at a of 0.11 to $0.60 \mathrm{~m}$, which is the recommended depth for soil preparation.
\end{abstract}

Keywords: physical soil, forest machines, traffic intensity. 


\section{INTRODUCTION}

Mechanization of wood harvesting operations has brought several benefits to the forestry sector, improving working conditions, ensuring industrial supply, increasing productivity and reducing production costs (Silva et al., 2007). However, the use of large machines for wood harvesting operations has led to an increase in soil compaction and is affecting the potential and sustainability of forest production (Seixas \& Souza, 2007).

Soil compaction results from the approximation of soil particles due to external stresses applied on the soil with a reduction of volume that increases density, thereby reducing porous space, infiltration and water movement, and consequently increasing mechanical resistance to root development (Reichert et al., 2007; Reichert et al., 2010).

Nowadays, soil compaction has been studied in forest plantations as it is affected by several factors, such as: organic matter content; soil texture and moisture; forest residues; machine dimension and weight; size and air pressure of the tires; and machine traffic intensity (Reichert et al., 2007; Lopes et al., 2011; Szymczak et al., 2014; Pincelli et al., 2014; Jesus et al., 2015; Sampietro et al., 2015).

In relation to these factors, traffic intensity is an important component that affects soil compaction during wood harvesting due to the use of large machines that usually travel several times over the same place. This situation contributes to increasing the soil compaction of these sites, causing alterations in the physical, chemical, and biological properties of the soil, and consequently in the sustainability of the forest ecosystem (Sampietro \& Lopes, 2011; 2016).

In Brazil, two wood harvesting systems predominate: cut to length, characterized by the use of a harvester and forwarder in which the trees are cut and processed in the interior of the stands and then shifted to the edge of the roads in the form of logs; and full trees, characterized by the use of a feller buncher, skidder and harvester, in which the trees are cut and dragged to the edge of the stands for final wood processing (Malinovski et al., 2014). The full tree system has lower operating costs and favors soil preparation by removing residual biomass. However, it causes the highest soil compaction due to the requirement for large machines and the trees being dragged directly over the soil.

For Silva et al. (2004), soil compaction is more intense in areas near the edges of the stand, caused by the highest machine traffic intensities at these site, and is a common situation in the full tree system. In addition, Greacen \& Sands (1980) affirm that timber harvesting operations do not cover every operational area, and therefore, a large degree of variability and heterogeneity of forest soil compaction and disturbance can occur.

On the other hand, it should be mentioned that soil compaction is greater in the first few wood harvesting machine passes and increases soil density along the traffic tracks which is related to the wheel types, the machine types used in the wood harvesting, and the number of passes (Seixas \& Souza, 2007; Sampietro \& Lopes, 2016).

Dias et al. (2003), when comparing two wood harvesting systems on an Oxisol, found that the impacts caused by the feller buncher and skidder were randomly distributed, covering a large area of the stand when compared to the harvester and forwarder system. Sampietro \& Lopes (2016) evaluated the cross section along a row of traffic of the feller buncher and skidder tractors in an Inceptisol by means of geostatistical techniques. The authors concluded that compaction was influenced by the soil moisture, which was above the field capacity, as well as by the increase in traffic intensity, leading to compaction of the deeper and more distant layers of the machine traffic trails.

Additionally, the importance of forest soil compaction studies is highlighted through its application to precision forestry concepts to maximize yields. Therefore, determining compaction levels along the stand after wood harvesting is important, since depending on the compaction levels observed, soil preparation can be carried out in a differentiated manner with consequent gains in productivity and cost reduction (Brandelero et al., 2007).

The aim of this study was to evaluate the effect of traffic by wood harvesting machines at different extraction distances, seeking information that could contribute to planning and operational cost reduction, as well as forest production sustainability. 


\section{MATERIAL AND METHODS}

This study was carried out at a forestry company located in the municipality of Telêmaco Borba, Paraná State, Brazil, between the geographical coordinates $24^{\circ} 19^{\prime} 37^{\prime \prime} \mathrm{S}$ and $50^{\circ} 36^{\prime} 58^{\prime \prime} \mathrm{W}$, in clear cut wood harvesting of seven-year old Eucalyptus grandis stands, at a spacing of $3.0 \mathrm{~m} \times 2.0 \mathrm{~m}$, an average number of 1,217 trees per hectare, and diameter, height and average volume per tree of $0.175 \mathrm{~m}, 26.5 \mathrm{~m}$ and $0.30 \mathrm{~m}^{3}$, respectively.

According to the Köppen climate classification system, the region is classified between $\mathrm{Cfa}$ and $\mathrm{Cfb}$ being predominantly $\mathrm{Cfa}$. It presents average temperatures lower than $18{ }^{\circ} \mathrm{C}$ in the coldest month and higher than $22^{\circ} \mathrm{C}$ in the warmest month. The annual average relative humidity is between 70 and $75 \%$, with average annual precipitation of 1,400 to $1,600 \mathrm{~mm}$.

The soil in the study area was classified as Oxisol, with a quantity of coarse sand, fine sand, silt and clay equal to $0.395 ; 0.238 ; 0.071$; and $0.296 \mathrm{~kg} \mathrm{~kg}^{-1}$, respectively, obtained by the pipette method (EMBRAPA, 1997). The carbon content in 0 to $0.60 \mathrm{~m}$ was $0.009 \mathrm{~kg} \mathrm{~kg}^{-1}$ and was obtained by the modified Walkley-Black method (Pavan et al., 1992). Soil moisture was determined by the gravimetric method, with average values of $0.28 ; 0.25 ; 0.27$; and $0.26 \mathrm{~kg} \mathrm{~kg}^{-1}$ at depths of 0 to 0.10 ; 0.11 to $0.20 ; 0.21$ to 0.40 ; and 0.41 to $0.60 \mathrm{~m}$, respectively.

An experiment was conducted in a full tree harvesting system. The felling and piling of the tree bundles was carried out by a feller buncher with $224 \mathrm{~kW}$ rated power, $31.3 \mathrm{Mg}$ operational weight, and equipped with tracks. Tree extraction by dragging from the interior to the edge of the stand was carried out by a forest tractor skidder with $6 \mathrm{WD}, 194 \mathrm{~kW}$ rated power, 21.4 Mg operational weight and equipped with wheels of A35.5 sizes and $241 \mathrm{kPa}$ inflation pressure. Finally, tree processing on the edge of the stands was carried out by a harvester tractor with $219 \mathrm{~kW}$ rated power, 28.7 Mg operational weight and tracks.

In the machine traffic row, a feller buncher pass occurred at the time of tree felling. Subsequently, an average of $14,10,6$, and 2 skidder passes were conducted during the extraction operation at the respective distance classes of 0 to $50 ; 51$ to $100 ; 101$ to 150 ; and 151 to $200 \mathrm{~m}$, taking into consideration the travel of an empty and loaded machine.
To evaluate the soil compaction caused along the extraction trails after the completed wood harvesting operations, undisturbed soil samples were obtained taking into consideration extraction distances of $25,75,125$, and $175 \mathrm{~m}$ in relation to the edge of the stand. These corresponded to the centers of the distance classes equal to 0 to 50,51 to 100,101 to 150 , and 151 to $200 \mathrm{~m}$, respectively; and in the center of the depths from 0 to $0.10,0.11$ to $0.20,0.21$ to 0.40 , and 0.41 to $0.60 \mathrm{~m}$. Twenty-four samples were obtained by depth, with six samples for each extraction distance class (in the traffic rows and between the traffic rows).

Soil density (Ds) and total porosity (Pt) were determined according to the methodology proposed by EMBRAPA (1997), in which the soil samples were collected with preserved structure using a Soil Control TAI sampler and volume rings of $0.0001 \mathrm{~m}^{3}$.

Soil penetration resistance (PR) was determined at the same points of the undisturbed samples using a Eijkelkamp 06.15.SA digital electronic penetrometer equipped with a cone-shaped tip, a vertex angle of $60^{\circ}$ and basis of $0.0001 \mathrm{~m}^{2}(11.28 \mathrm{~mm}$ of nominal diameter). Maximum velocity of soil penetration was established at $0.02 \mathrm{~m} \mathrm{~s}^{-1}$, being performed by an operator controlled by an internal sensor which maintained the penetrometry pressure constant.

Seven sample points were established at different transverse positions along the machine traffic rows, with known distances for PR determination up to $0.60 \mathrm{~m}$ depth. Using the soil penetration resistance points, we obtained averages in the traffic row positions, between traffic rows, and off traffic rows, with these being equal to $0.25 \mathrm{~m}$ of the row distance.

The experiment was conducted in transects with three replications in bands along the extraction distances, in which the occurrences of the studied phenomenon were measured. For this reason, the results obtained were submitted to normality testing and the averages of the extraction distances were compared by the Fisher DMS test (multiple t-test) at a 5\% probability of error level. Cross-sectional thematic maps of soil penetration resistance were composed in the four extraction distance classes using Surfer 8.0 software using the values estimated by kriging interpolation and parameters of fitted semivariograms were performed with GS+ software. 


\section{RESULTS}

Table 1 shows the soil density outcomes at different soil depths after wood harvesting machine traffic from variable extraction distances. The highest soil density values were found in the distance classes from 0 to $50 \mathrm{~m}$ and 51 to $100 \mathrm{~m}$ where there was the highest machine traffic intensity, ranging between $1.96 \mathrm{Mg} \mathrm{m}^{-3}$ in 0 to $0.10 \mathrm{~m}$, and $1.76 \mathrm{Mg} \mathrm{m}^{-3}$ in 0.41 to $0.60 \mathrm{~m}$ depth. Also, the difference between these two extraction distance classes was not statistically significant by the Fisher DMS test at the $5 \%$ probability level.

Significant differences in soil density were observed for the different extraction distance classes in the deepest soil layers of 0.11 to $0.60 \mathrm{~m}$. Distance classes near to the stand edge where there was the highest traffic intensity differed from the lowest intensity classes. These results prove that soil compaction caused by the wood harvesting machine traffic occurs in a systematic way, with the highest compaction occurring at the edge of the stands and decreasing towards the center of the stands (Dias et al., 2003; Silva et al., 2004; Reichert et al., 2007).

The definition of critical compaction sites in a forest stand contribute to the application of specific management techniques for each affected area. Therefore, it is possible to reduce the time and costs of soil preparation operations (Reichert et al., 2007). However, it should be highlighted that all the soil density values obtained after wood harvesting, both in distance classes and depths, reached the critical density values for tree development. According to the equation proposed by Reichert et al. (2009), for soil with an average clay content of $0.298 ; 0.305 ; 0.295$; and $0.285 \mathrm{~kg} \mathrm{~kg}^{-1}$ at depths of 0 to $0.10 ; 0.11$ to 0.20 ; 0.21 to 0.40 ; and 0.41 to $0.60 \mathrm{~m}$, respectively, there is an average critical density of $1.61 \mathrm{Mg} \mathrm{m}^{-3}$ for all depths.

In Table 2, it is possible to observe that total porosity values in the superficial soil layer ( 0 to $0.10 \mathrm{~m}$ ) did not present significant statistical differences in most of the distance classes, except in the class 101 to $150 \mathrm{~m}$. While the treatments differed in the intermediate soil layers due to the increase in the number of machines passes.

Average values of soil penetration resistance (PR) for different extraction distances and depths after the wood harvesting machine traffic are shown in Table 3. In the traffic row position, the surface layer ( 0 to $0.10 \mathrm{~m}$ ) did not present significant statistical difference between the extraction distances, in which the soil penetration resistance values ranged from 1.97 to $1.68 \mathrm{MPa}$. These

Table 1. Average soil density values at different extraction distances and depths after wood harvesting machine traffic.

\begin{tabular}{|c|c|c|c|c|c|c|c|c|}
\hline \multirow{3}{*}{$\begin{array}{l}\text { Soil depth } \\
\text { (m) }\end{array}$} & \multicolumn{4}{|c|}{ Distance classes (m) } & \multirow{2}{*}{ Average } & \multirow{3}{*}{ Value F } & \multirow{3}{*}{ DMS } & \multirow{3}{*}{$\begin{array}{l}\text { CV } \\
(\%)\end{array}$} \\
\hline & $0-50$ & $51-100$ & 101-150 & $151-200$ & & & & \\
\hline & \multicolumn{5}{|c|}{ Ds $\left(\mathrm{Mg} \mathrm{m}^{-3}\right)$} & & & \\
\hline 0-0.10 & $1.96 \mathrm{a}( \pm 0.13)$ & $1.91 \mathrm{ab}( \pm 0.19)$ & $1.74 \mathrm{~b}( \pm 0.20)$ & $1.82 \mathrm{ab}( \pm 0.13)$ & 1.86 & $1.9^{*}$ & 0.20 & 9.11 \\
\hline $0.11-0.20$ & 1.96 a $( \pm 0.02)$ & $1.88 \mathrm{ab}( \pm 0.13)$ & $1.74 \mathrm{c}( \pm 0.13)$ & $1.77 \mathrm{bc}( \pm 0.10)$ & 1.84 & $6.2^{\star *}$ & 0.12 & 5.47 \\
\hline $0.21-0.40$ & $1.94 \mathrm{a}( \pm 0.01)$ & $1.85 \mathrm{ab}( \pm 0.10)$ & $1.77 \mathrm{bc}( \pm 0.11)$ & $1.69 c( \pm 0.10)$ & 1.81 & $7.9^{* *}$ & 0.11 & 5.15 \\
\hline $0.41-0.60$ & $1.88 \mathrm{a}( \pm 0.03)$ & $1.76 \mathrm{ab}( \pm 0.16)$ & $1.73 \mathrm{~b}( \pm 0.12)$ & $1.64 \mathrm{~b}( \pm 0.08)$ & 1.75 & $4.9^{*}$ & 0.13 & 6.25 \\
\hline
\end{tabular}

Where: Averages followed by different letters indicate significant differences by the DMS test $(\alpha=0.05)$ in distance classes and same soil depth (lines). ${ }^{*}$ significant at $5 \%$; ${ }^{* *}$ significant at $1 \%$.

Table 2. Average total porosity values in the different extraction distances and depths after the wood harvesting machine traffic.

\begin{tabular}{|c|c|c|c|c|c|c|c|c|}
\hline \multirow{3}{*}{$\begin{array}{l}\text { Soil depth } \\
\text { (m) }\end{array}$} & \multicolumn{4}{|c|}{ Distance classes (m) } & \multirow{2}{*}{ Average } & \multirow{3}{*}{ Value F } & \multirow{3}{*}{ DMS } & \multirow{3}{*}{$\begin{array}{l}\text { CV } \\
(\%)\end{array}$} \\
\hline & 0-50 & $51-100$ & $101-150$ & $151-200$ & & & & \\
\hline & \multicolumn{5}{|c|}{$\mathbf{P t}\left(\mathrm{m}^{3} \mathrm{~m}^{-3}\right)$} & & & \\
\hline $0-0.10$ & $0.265 \mathrm{~b}( \pm 0.051)$ & $0.284 \mathrm{ab}( \pm 0.072)$ & $0.345 \mathrm{a}( \pm 0.075)$ & $0.316 \mathrm{ab}( \pm 0.052)$ & 0.303 & $1.9^{*}$ & 0.08 & 20.99 \\
\hline $0.11-0.20$ & $0.264 \mathrm{~b}( \pm 0.008)$ & $0.310 \mathrm{a}( \pm 0.036)$ & $0.347 \mathrm{a}( \pm 0.050)$ & $0.337 \mathrm{a}( \pm 0.021)$ & 0.314 & $7.5^{\star *}$ & 0.04 & 10.57 \\
\hline $0.21-0.40$ & $0.272 \mathrm{c}( \pm 0.002)$ & $0.305 \mathrm{bc}( \pm 0.041)$ & $0.335 \mathrm{ab}( \pm 0.041)$ & $0.366 \mathrm{a}( \pm 0.039)$ & 0.319 & $7.9^{* *}$ & 0.04 & 10.97 \\
\hline $0.41-0.60$ & $0.295 \mathrm{~b}( \pm 0.001)$ & $0.341 \mathrm{ab}( \pm 0.065)$ & $0.351 \mathrm{a}( \pm 0.045)$ & $0.384 \mathrm{a}( \pm 0.029)$ & 0.343 & $4.8^{*}$ & 0.05 & 11.99 \\
\hline
\end{tabular}

Where: Averages followed by different letters indicate significant differences by DMS test $(\alpha=0.05)$ in distance classes and same depth of soil (lines). ${ }^{*}$ significant at $5 \%$; ${ }^{* *}$ significant at $1 \%$. 
values are below $2 \mathrm{MPa}$, considered critical for tree development (Greacen \& Sands, 1980; Whalley et al., 1995). However, the soil penetration resistance exceeded $2 \mathrm{MPa}$ in other soil depths, showing the need to adopt mitigating actions to reduce soil compaction, as well as the need for the greatest intervention in soil preparation for forest implantation.

We observed that the PR presented a statistically significant difference in relation to other extraction distances at a depth of 0.11 to $0.60 \mathrm{~m}$ and distance classes of 0 to 50 and 51 to $100 \mathrm{~m}$ (in which there was the highest traffic intensity). This behavior represented the highest values and demonstrated the effect of the intensity that occurs in this region of the stand.

In the position between the traffic row and off the traffic row of the machines, we also observed the effects on the sides of the soil profile. This had the smallest magnitude in relation to the traffic row position however, and it did not reach the critical value for tree development. Additionally, the values in the first distance classes for a depth of 0.11 to $0.60 \mathrm{~m}$ were the statistically highest difference in relation to other extraction distances.

Table 4 shows the fits obtained in the construction and analysis of the semivariograms for soil penetration resistance at different extraction distances. These values obtained were used to produce the transversal penetrometric profile of the distance classes evaluated after the wood harvesting operations (Figure 1).

In the traffic row positions, soil compaction tended to be highest with the increase of machine passings. The greatest changes in soil compaction were observed at a distance of 0 to $50 \mathrm{~m}$ with one feller buncher pass and 14 skidder passes, represented by the dark color

Table 3. Average soil penetration resistance values of different extraction distances and depths after the wood harvesting machine traffic.

\begin{tabular}{|c|c|c|c|c|c|c|c|c|}
\hline \multirow{3}{*}{$\begin{array}{l}\text { Soil } \\
\text { depth } \\
\text { (m) }\end{array}$} & \multicolumn{4}{|c|}{ Distance classes (m) } & \multirow{3}{*}{ Average } & \multirow{3}{*}{ Value F } & \multirow{3}{*}{ DMS } & \multirow{3}{*}{$\begin{array}{l}\text { CV } \\
(\%)\end{array}$} \\
\hline & 0-50 & $51-100$ & 101-150 & 151-200 & & & & \\
\hline & \multicolumn{4}{|c|}{ PR (MPa) } & & & & \\
\hline \multicolumn{9}{|c|}{ Traffic rows } \\
\hline 0-0.10 & 1.969 a $( \pm 0.551)$ & $1.934 \mathrm{a}( \pm 0.301)$ & 1.878 a $( \pm 0.501)$ & $1.679 \mathrm{a}( \pm 0.505)$ & 1.865 & $0.8^{\mathrm{ns}}$ & 0.41 & 25.43 \\
\hline $0.11-0.20$ & $2.271 \mathrm{a}( \pm 0.044)$ & $2.285 \mathrm{a}( \pm 0.053)$ & $2.187 \mathrm{~b}( \pm 0.014)$ & $2.132 c( \pm 0.031)$ & 2.212 & $41.7^{\star \star}$ & 0.03 & 1.60 \\
\hline $0.21-0.40$ & $2.229 \mathrm{~b}( \pm 0.0 .60)$ & $2.356 \mathrm{a}( \pm 0.012)$ & $2.157 \mathrm{~d}( \pm 0.013)$ & $2.189 c( \pm 0.036)$ & 2.233 & $116.5^{\star *}$ & 0.02 & 1.62 \\
\hline $0.41-0.60$ & $2.418 \mathrm{~b}( \pm 0.010)$ & $2.484 \mathrm{a}( \pm 0.075)$ & $2.198 \mathrm{c}( \pm 0.018)$ & $2.050 \mathrm{~d}( \pm 0.047)$ & 2.287 & $323.7^{\star \star}$ & 0.03 & 2.17 \\
\hline \multicolumn{9}{|c|}{ Between traffic rows } \\
\hline 0-0.10 & $1.412 \mathrm{a}( \pm 0.366)$ & $1.408 \mathrm{a}( \pm 0.148)$ & $1.451 \mathrm{a}( \pm 0.367)$ & $1.359 \mathrm{a}( \pm 0.345)$ & 1.408 & $0.2^{\mathrm{ns}}$ & 0.28 & 22.72 \\
\hline $0.11-0.20$ & 1.652 a $( \pm 0.028)$ & $1.503 \mathrm{c}( \pm 0.006)$ & $1.636 \mathrm{a}( \pm 0.016)$ & $1.554 \mathrm{~b}( \pm 0.015)$ & 1.586 & $152.6^{* *}$ & 0.02 & 1.13 \\
\hline $0.21-0.40$ & $1.630 \mathrm{a}( \pm 0.057)$ & $1.493 \mathrm{c}( \pm 0.016)$ & 1.650 a $( \pm 0.031)$ & $1.515 \mathrm{~b}( \pm 0.008)$ & 1.572 & $110.0^{* *}$ & 0.02 & 2.15 \\
\hline $0.41-0.60$ & $2.101 \mathrm{a}( \pm 0.116)$ & $1.504 \mathrm{~d}( \pm 0.026)$ & $1.722 \mathrm{~b}( \pm 0.025)$ & $1.560 \mathrm{c}( \pm 0.016)$ & 1.722 & $384.3^{* *}$ & 0.04 & 3.57 \\
\hline \multicolumn{9}{|c|}{ Off the traffic rows } \\
\hline 0-0.10 & 1.215 a $( \pm 0.349)$ & $1.241 \mathrm{a}( \pm 0.120)$ & $1.202 \mathrm{a}( \pm 0.238)$ & $1.111 \mathrm{a}( \pm 0.094)$ & 1.192 & $17.8^{\star *}$ & 0.19 & 18.82 \\
\hline $0.11-0.20$ & $1.483 \mathrm{a}( \pm 0.005)$ & $1.291 \mathrm{c}( \pm 0.010)$ & $1.307 \mathrm{~b}( \pm 0.002)$ & $1.170 \mathrm{~d}( \pm 0.002)$ & 1.313 & $17.9^{* *}$ & 0.01 & 0.41 \\
\hline $0.21-0.40$ & $1.571 \mathrm{a}( \pm 0.044)$ & $1.255 \mathrm{c}( \pm 0.040)$ & $1.435 \mathrm{~b}( \pm 0.161)$ & $1.217 \mathrm{c}( \pm 0.047)$ & 1.370 & $27.8^{\star \star}$ & 0.06 & 6.50 \\
\hline $0.41-0.60$ & $1.595 \mathrm{~b}( \pm 0.008)$ & $1.390 \mathrm{c}( \pm 0.066)$ & $1.634 \mathrm{a}( \pm 0.018)$ & $1.370 \mathrm{c}( \pm 0.047)$ & 1.497 & $64.3^{\star *}$ & 0.03 & 2.79 \\
\hline
\end{tabular}

Where: Averages followed by different letters indicate significant differences by DMS test $(\alpha=0.05)$ in distance classes and same depth of soil (lines); ${ }^{*}$ significant at $5 \%$; ${ }^{* *}$ significant at $1 \%$; ${ }^{\text {ns: }}$ non-significant; RP: soil resistance to penetration; DMS: minimum significant difference; $\mathrm{CV}$ : coefficient of variation.

Table 4. Parameters of semivariogram fitted for soil penetration resistance.

\begin{tabular}{cccccccc}
$\begin{array}{c}\text { Distance } \\
\text { class }(\mathbf{m})\end{array}$ & Model & $\mathbf{C}_{\mathbf{0}}$ & $\mathbf{C}_{\mathbf{0}}+\mathbf{C}_{\mathbf{1}}$ & $\mathbf{A}(\mathbf{m})$ & $\mathbf{R}^{2}$ & SPI & DSD \\
\hline $\mathbf{0 - 5 0}$ & Sph & 0.0268874 & 0.1445004 & 1.8 & 0.001 & 0.814 & Strong \\
$\mathbf{5 1 - 1 0 0}$ & Sph & 0.0305255 & 0.193746 & 2.0 & 0.004 & 0.842 & Strong \\
$\mathbf{1 0 1 - 1 5 0}$ & Exp & 0.0333688 & 0.197861 & 2.1 & 0.005 & 0.831 & Strong \\
$\mathbf{1 5 1 - 2 0 0}$ & Sph & 0.0394000 & 0.181800 & 2.6 & 0.058 & 0.783 & Strong \\
\hline
\end{tabular}

Where: Exp = exponential model; $\mathrm{Sph}=$ spherical model; $\mathrm{C}_{0}=$ nugget effect; $\mathrm{C}_{0}+\mathrm{C}_{1}=$ sill; $\mathrm{A}=$ range; $\mathrm{SPI}=$ spatial dependence index; $\mathrm{R}^{2}=$ coefficient of determination of the model; and DSD = degree of spatial dependence. 

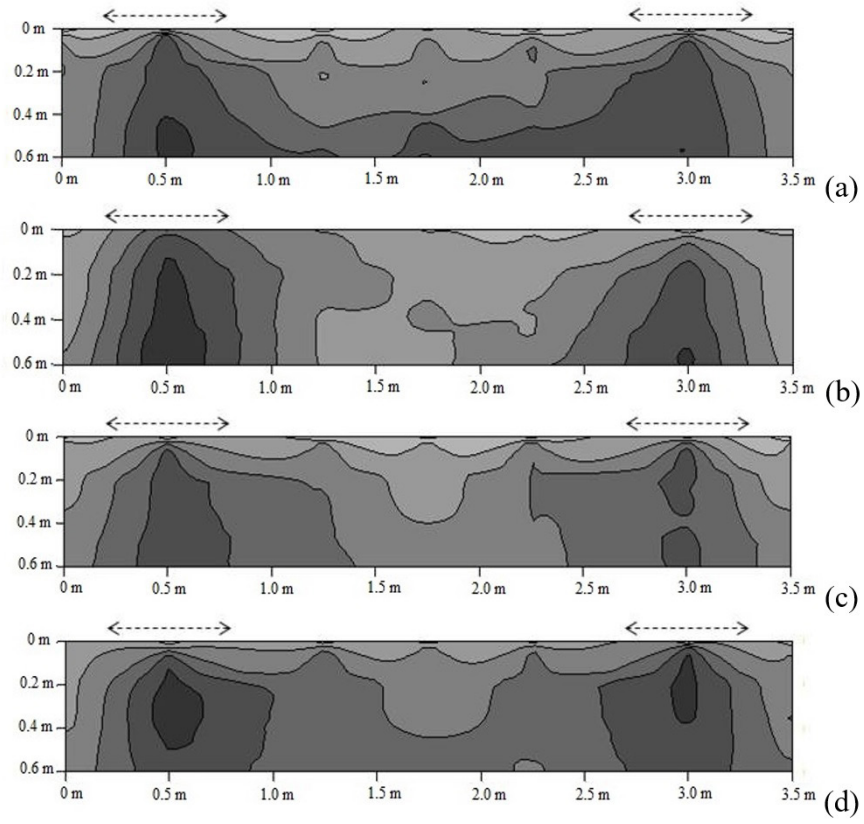

Soil penetration resistance (MPa)

\begin{tabular}{|l|l|l|l|l|l|l|l|l|l|l|}
\hline 0 & 0.3 & 0.6 & 0.9 & 1.2 & 1.5 & 1.8 & 2.1 & 2.4 & 2.7 & 3.0 \\
\hline & & & & & & & & & & \\
\hline
\end{tabular}

Figure 1. Effect of soil penetration resistance along the soil profile in the full tree system for the distances: (a) 0-50 m; (b) $51-100 \mathrm{~m}$; (c) $101-150 \mathrm{~m}$; and (d) 151-200 m. Legend shows the values of soil penetration resistance. Arrows indicate the traffic row position.

which corresponds to critical values above $2 \mathrm{MPa}$ according to soil penetration resistance. Meanwhile, in positions between traffic rows and off the traffic rows there were changes that are considered residual, with the lowest values in comparison to the traffic row position. However, heavy traffic could have affected areas beyond the machine's runway trails, particularly in terms of depth.

\section{DISCUSSION}

According to the evaluated physical soil parameters, the highest soil compaction caused by the wood harvesting machine traffic was evident in the deepest soil layers, traffic row of the machine, and near the edge of the stand.

Several studies have evaluated the impact of machine traffic intensity on soil compaction, especially Lima et al. (2008) who studied the traffic intensity of feller bunchers and skidders in Eucalyptus spp. stand on Oxisol, concluding that the machine traffic affected the PR up to $0.45 \mathrm{~m}$ of depth. Sampietro \& Lopes (2016) in studying an Inceptisol verified that an increase in the number of feller bunchers and skidders caused an intensification of soil penetration resistance after the first machine passes, with the clearest signs in the deepest soil layers.

However, these studies did not show if the soil penetration resistance variability occurred routinely within the stand, since it is a characteristic of forest extraction activity. Thus, this variability may influence the reform activities of the stands, and directly affect the soil preparation activities. Therefore, this study suggests a need to adopt efficient planning of forest operations and a differentiated soil preparation along the stand according to the soil compaction intensity, thereby reducing energy consumption and operating costs.

Moreover, only areas near the edge of the stand and on the machine traffic trails need more intensive soil preparation, being a technique for more efficient forestry which can contribute to reducing the forestry operation costs.

The cross-sectional thematic maps of soil penetration resistance can be used as an efficient tool to realize 
precision forestry due to the highest effects caused by the machine traffic occurring below the traffic row, as well as the lowest intensities being observed on the sides of the stand. According to Håkansson \& Voorhees (1997), these behaviors can be caused by the characteristics of the wheelsets, mainly from the inflation pressure and total axle load of the machines, and the use of large machines to drag the trees directly in contact with the ground.

Finally, this study has shown that forest management based on spatial distribution information could be used as a basis for strategic decision-making to conduct forestry operations with greater efficiency and fewer errors and costs.

\section{CONCLUSIONS}

- Wood harvesting machine traffic causes the highest density increases and reduced porosity in the superficial soil layers, in the machine traffic rows, and near the edge of the stand, with values above critical limits;

- An increase in the number of skidder passes in the distance classes close to the edge of the stand increased soil compaction;

- Soil penetration resistance is more critical in the machine traffic rows, with effects at depths of 0.11 to $0.60 \mathrm{~m}$ in comparison with other evaluated positions;

- Soil preparation must be carried out with the same intensity along the stand in the traffic tracks of the machines up to a depth of $0.60 \mathrm{~m}$ and in the areas near the sides of the stands;

- Soil compaction spatial location can support precision forestry techniques through differentiated soil preparation within the stand, leading to gains in productivity and operating cost reductions.

\section{ACKNOWLEDGEMENTS}

The authors would like to acknowledge the forestry company for its support throughout this research.

\section{SUBMISSION STATUS}

Received: 3 feb., 2016

Accepted: 2 june 2017

\section{CORRESPONDENCE TO}

\section{Carla Krulikowski Rodrigues}

Programa de Pós-graduação em Ciências

Florestais, Universidade Estadual do

Centro-Oeste - UNICENTRO, PR 153, Km 07, Riozinho, CP 21, CEP 84500-000, Irati, PR, Brazil e-mail: carlakr@gmail.com

\section{FINANCIAL SUPPORT}

This work was supported by the CAPES with postgraduate scholarships.

\section{REFERENCES}

Brandelero C, Antunes MUF, Giotto E. Silvicultura de precisão: nova tecnologia para o desenvolvimento florestal. Ambiência 2007; 3(2): 269-281.

Dias MS Jr, Leite FP, Winter ME, Pires JVG. Avaliação quantitativa da sustentabilidade estrutural de um Latossolo Vermelho-Amarelo cultivado com eucalipto na região de Peçanha-MG. Revista Árvore 2003; 27(3): 343-349. http://dx.doi.org/10.1590/S0100-67622003000300010.

Empresa Brasileira de Pesquisa Agropecuária - EMBRAPA. Centro Nacional de Pesquisa do Solo. Manual de métodos de análise de solo. 2. ed. Rio de Janeiro: EMBRAPA; 1997.

Greacen EL, Sands R. Compaction of forest soils: a review. Australian Journal of Soil Research 1980; 18(1): 163-169. http://dx.doi.org/10.1071/SR9800163.

Håkansson I, Voorhees WB. Soil compaction. In: Lal R, Blum WEH, Valentin C, Stewart BA. Methods for assessment of soil degradation. Boca Raton: Lewis; 1997.

Jesus GL, Silva IR, Almeida LFJ, Santos MA, Leite FP, Neves JCL. Produtividade do eucalipto, atributos físicos do solo e frações da matéria orgânica influenciadas pela intensidade de tráfego e resíduos de colheita. Revista Brasileira de Ciência do Solo 2015; 39(4): 1190-1203. http:// dx.doi.org/10.1590/01000683rbcs20140494.

Lima JSS, Oliveira PC, Oliveira RB, Xavier AC. Métodos geoestatísticos no estudo da resistência do solo à penetração em trilha de tráfego de tratores na colheita de madeira. Revista Árvore 2008; 32(5): 931-938. http://dx.doi. org/10.1590/S0100-67622008000500018.

Lopes ES, Sampietro JA, Lombardi KC, Dias AN. Avaliação da umidade na compactação do solo submetido ao tráfego de máquinas de colheita florestal. Revista Árvore 2011; 35(3): 659-667. http://dx.doi.org/10.1590/S010067622011000400010 . 
Malinovski JR, Camargo CMS, Malinovski RA, Malinovski RA. Sistemas. In: Machado CC. Colheita florestal. Viçosa: UFV. 3. ed. Viçosa: UFV; 2014.

Pavan MA, Bloch MF, Zempulski HC, Miyazawa M, Zocoler DC. Manual de análise química de solo e controle de qualidade. Londrina: IAPAR; 1992.

Pincelli ALPSM, Seixas F, Nunes R. Compactação e fertilidade do solo após colheita do eucalipto utilizando feller buncher e skidder. Cerne 2014; 20(2): 191-198. http:// dx.doi.org/10.1590/01047760.201420021414.

Reichert JM, Reinert DJ, Suzuki LEAS, Horn R. Mecânica do solo. In: Van Lier QJ. Física do solo. Viçosa: Sociedade Brasileira de Ciência do Solo; 2010.

Reichert JM, Suzuki LEAS, Reinert DJ, Horn R, Hakansson I. Reference bulk density and critical degree-of-compactness for no-till crop production in subtropical highly weathered soils. Soil \& Tillage Research 2009; 102(2): 242-254. http:// dx.doi.org/10.1016/j.still.2008.07.002.

Reichert JM, Suzuki LEAS, Reinert DJ. Compactação do solo em sistemas agropecuários e florestais: identificação, efeitos, limites críticos e mitigação. In: Cereta CA, Silva LS, Reichert JM. Tópicos em ciência do solo. Viçosa: Sociedade Brasileira de Ciência do solo; 2007.

Sampietro JA, Lopes ES, Reichert JM. Compactação causada pelo tráfego de feller buncher e skidder em um neossolo regolítico sob distintas umidades. Ciência Florestal 2015; 25(1): 239-248. http://dx.doi.org/10.5902/1980509817482.
Sampietro JA, Lopes ES. Compactação de um cambissolo causada por máquinas de colheita florestal espacializada com geoestatística. Floresta 2016; 46(3): 307-314. http:// dx.doi.org/10.5380/rf.v46i3.37217.

Sampietro JA, Lopes ES. Compactação de um Cambissolo e Neossolo submetidos a diferentes intensidades de tráfego de Feller Buncher e Skidder. Scientia Forestalis 2011; 39(90): 265-272.

Seixas F, Souza CR. Avaliação e efeito da compactação do solo devido à frequência de tráfego na produção de madeira de eucalipto. Revista Árvore 2007; 31(6): 1047 1052. http://dx.doi.org/10.1590/S0100-67622007000600009.

Silva SR, Barros NF, Costa LM, Mendonça ES, Leite FP. Alterações do solo influenciadas pelo tráfego e carga de um forwarder nas entrelinhas de uma floresta de eucalipto. Revista Brasileira de Ciência do Solo 2007; 31(2):371-377. http://dx.doi.org/10.1590/S0100-06832007000200019.

Silva VR, Reichert JM, Reinert DJ. Variabilidade espacial da resistência do solo à penetração em plantio direto. Ciência Rural 2004; 34(2): 399-406. http://dx.doi.org/10.1590/ S0103-84782004000200010.

Szymczak DA, Brun EJ, Reinert DJ, Frigotto T, Mazzalira CC, Dal'Col Lúcio A et al. Compactação do solo causada por tratores florestais na colheita de Pinus taeda L. na região sudoeste do Paraná. Revista Árvore 2014; 38(4): 641-648. http://dx.doi.org/10.1590/S0100-67622014000400007.

Whalley WR, Dumitru E, Dexter AR. Biological effects of soil compaction. Soil \& Tillage Research 1995; 35(1): 53-68. http://dx.doi.org/10.1016/0167-1987(95)00473-6. 